\title{
$\mathrm{Ni}$ 基超合金 Alloy 706 のピーニング施工材の熱時効処理による
}

\author{
圧縮残留応力緩和挙動の評価 ${ }^{\dagger}$

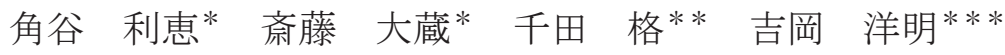 \\ 石橋 和利 $* * * *$ 小林 大輔 $* * * * *$ 伊藤 明洋 $* * * * *$ \\ 宮部 正道 $* * * * *$ 阿知波 雅宏 $* * * * *$ 岸本 喜久雄 $* * * * * *$
}

\section{Evaluation on Relaxation Behaviors of Compressive Residual Stress of Peened Ni-Base Superalloy Alloy 706 Test Specimens after Thermal Aging Treatment}

by

\author{
Rie Sumiy**, Daizo Saito, Itaru ChidA**, Yomei YoshiokA***, \\ Kazutoshi Ishibashi $* * * *$, Daisuke KoвaYAshi*****, Akihiro Iто*****, \\ Masamichi Miyabe*****, Masahiro Achiwa***** and Kikuo Kishimoto******
}

\begin{abstract}
The operating lifetime of the components made of a large-scale forged material, such as the power generating components in a thermal power plant, is influenced by the initiation of defects such as cracks. Peening is known to be effective for the improvement of fatigue strength and the prevention of the stress corrosion cracking initiation. Shot peening that generates compressive residual stress on the material surface is applied to the stress concentration region of the high-strength large-scale forged material in order to relax the tensile stress, prevents crack initiation and extends operation lifetime. To confirm the durability of the compressive residual stress generated by peening, the influence of thermal aging treatment on the compressive residual stress is evaluated. As a result, it is reported that compression is maintained though compressive residual stress relaxes. The purpose of this study is to develop evaluation method of the relaxation behavior of residual stress generated by shot peening and laser peening during actual plant operations. Shot peening and laser peening were performed on the specimens of Ni-base superalloy Alloy 706, which is used as the material of the discs of gas turbines, and the thermal aging treatment test was performed. It shows that the compressive residual stress decreases to an elastic limit after heating and then relaxes due to creep strain generation. It is found that residual stress was almost determined by the residual stress just after heating.
\end{abstract}

\section{Key words:}

Residual stress, Relaxation, Laser peening, Shot peening, Creep, Ni-base superalloy Alloy 706

\section{1 緒言}

火力プラントの発電設備等の大型鍛造材の運転寿命は き裂等の欠陥の発生の影響をうける。ピーニングは，疲 労強度向上や応力腐食割れ発生の予防に効果があること が知られており，高強度大型鍛造材の応力集中部の応力 緩和とき裂発生の予防，また，寿命延伸のためにピー二 ングによる圧縮残留応力付与が行われている. その圧縮 残留応力の持続性の確認として, 圧縮残留応力に及ぼす 熱処理の影響評価がなされており，残留応力が緩和する ものの圧縮が維持されることが報告されている ${ }^{1) \sim 6)}$.レー

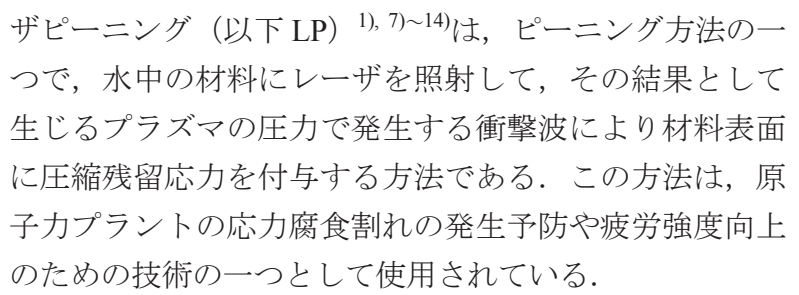

$\mathrm{Ni}$ 基超合金 Alloy 706 は，ガスタービンのホイールの 材料として使用されており，この部位には寿命延伸のた めにショットピーニング (以下 SP) を施工されている部 位もある。この部位のように高温環境下で使用される材

原稿受理 平成27年4月3日 Received Apr.3, 2015 C2016 The Society of Materials Science, Japan

正 会 員 (株)東芝 電カシステム社 テ230-0045 横浜市鶴見区未広町

Toshiba Corporation Power Systems Company, Tsurumi-ku, Yokohama 230-0045.

**（株)東芝 電力システム社 厂235-8523 横浜市磯子区新杉田町

Toshiba Corporation Power Systems Company, Isogo-ku, Yokohama 235-8523.

*** 正会員 元 (株)東芝 電力システム社 テ212-0013 川崎市幸区堀川町

Toshiba Corporation Power Systems Company, Saiwai-ku, Kawasaki 212-0013.

****（株)東芝 電力システム社 †212-0013 川崎市幸区堀川町

Toshiba Corporation Power Systems Company, Saiwai-ku, Kawasaki 212-0013.

****** 正 会 員 中部電力(株) 電力技術研究所 $\overline{7} 459-8522$ 名古屋市緑区大高町

Chubu Electric Power Co., Inc., Electric Power Research \& Development Center, Midori-ku, Nagoya 459-8522

****** 正 会 員 東京工業大学 大学院理工学研究科 ₹152-8552 東京都目黒区大岡山

Tokyo Institute of Technology, graduate School of Science and Engineering, Meguro-ku, Tokyo 152-8552. 
料に圧縮残留応力を付与した場合の残留応力緩和挙動を 把握することは機器の健全性評価においても意義がある. そこで，この材料に LP および SP を施工して，熱時効処 理試験を実施し，クリープが生じる温度においても圧縮 残留応力が維持されていることを確認する，加えて，圧 縮残留応力の緩和評価手法を検討し，残留応力の予測方 法を確立する。

\section{2 供試材および試験方法}

\section{1 供試材}

供試材は，ガスタービンのホイールの材料として使用 されているNi基超合金 Alloy 706である. Table 1に化学 成分を, Fig. 1 に機械的特性として室温から $600^{\circ} \mathrm{C}$ までの 引張試験結果を, Table 2にヤング率 $E^{15)}$ を示す。供試材 の引張試験結果として, $0.2 \%$ 而力 $\sigma_{0.2}$, 引張強さ $\sigma_{u}$, 弾性 限度 $\sigma_{E}$, 伸び $\delta$, 絞り $\varphi$ を示している。 この材料の $0.2 \%$ 耐 力は室温で962MPa, $600^{\circ} \mathrm{C}$ で842MPaである.

高温環境下における残留応力緩和はクリープひずみ の発生に起因すると考えられる. その予測を行うために, 平行部の径が $6 \mathrm{~mm}$ のつば付き円形断面試験片（JIS Z 2271）を用いて，Table 3に示す条件でクリープ試験を実 施した。定常クリープ領域を次式で表わし，パラメータ $A, n, m$ を最小2乗法で求めた. その結果をTable 4に示す.

$$
d \varepsilon_{c} / d t=A \sigma^{n} t^{m}
$$

ここで， $\varepsilon_{c}$ はクリープひずみ $(\%), \sigma$ は応力（ $\left.\mathrm{MPa}\right)$, tは時間（h）である。

\section{2 熱時効処理試験方法}

クリープが生じる温度において，ピーニングによる圧 縮残留応力の緩和挙動を評価するため, 熱時効処理試験 を行う。試験片形状をFig. 2に示す。試験片は $50 \mathrm{~mm} \times$ $50 \mathrm{~mm} \times 30 \mathrm{~mm}$ のブロックで, その一面 $(50 \times 50 \mathrm{~mm}$ の面 $)$ にピーニングを実施した.SPの施工条件は実機ロータホ イールに施工している施工条件と同一条件であり, LP の施工条件はTable 5に示寸条件である. SPに関しては, ほかの面をマスキングして施工した，LPに関しては，ス

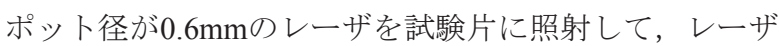
を走査して施工をした。これらのピーニング施工をした 試験片を用いて熱時効処理試験を実施し，試験前後の残 留応力をX線回折法にて測定した.

Table 6およびTable 7に試験マトリクスを示す.

熱時効処理温度は, SP材では $450^{\circ} \mathrm{C}$ から $630^{\circ} \mathrm{C}$ ま゙, LP 材では $450^{\circ} \mathrm{C}$ と $500^{\circ} \mathrm{C}$ である. 熱時効処理の雾囲気は大気 環境で，約 $200^{\circ} \mathrm{C} / \mathrm{h}$ で所定温度まで昇温後，設定時間保持 した。 その後，室温までの泠却を加熱炉内で行った。 $450^{\circ} \mathrm{C}$ は実使用最高温度で, $500^{\circ} \mathrm{C}$ はその温度を $50^{\circ} \mathrm{C}$ 加速 した条件であり，それらの温度で10000時間までの熱時 効処理を行った. $570^{\circ} \mathrm{C}$ から $630^{\circ} \mathrm{C}$ はリープ試験を実施 した温度であり，1000時間までの熱時効処理を行った。 $570^{\circ} \mathrm{C}$ から $630^{\circ} \mathrm{C}$ の熱時効処理試験結果とクリープ試験 結果から，残留応力緩和予測評価を行い，それらの結果 を踏まえて, $450^{\circ} \mathrm{C} と 500^{\circ} \mathrm{C}$ の残留応力緩和予測評価を行 った.
Table 1 Chemical compositions of test material. (Alloy 706)

\begin{tabular}{c|c|c|c|c}
\hline $\mathrm{Ni}$ & $\mathrm{Cr}$ & $\mathrm{Fe}$ & $\mathrm{Nb}$ & $\mathrm{Ti}$ \\
\hline 41.37 & 16.37 & $\mathrm{Bal}$ & 2.9 & 1.66 \\
\hline \hline $\mathrm{Al}$ & $\mathrm{C}$ & $\mathrm{S}$ & $\mathrm{P}$ & $\mathrm{B}$ \\
\hline 0.2 & 0.015 & $<.0005$ & 0.006 & 0.0039 \\
\hline
\end{tabular}

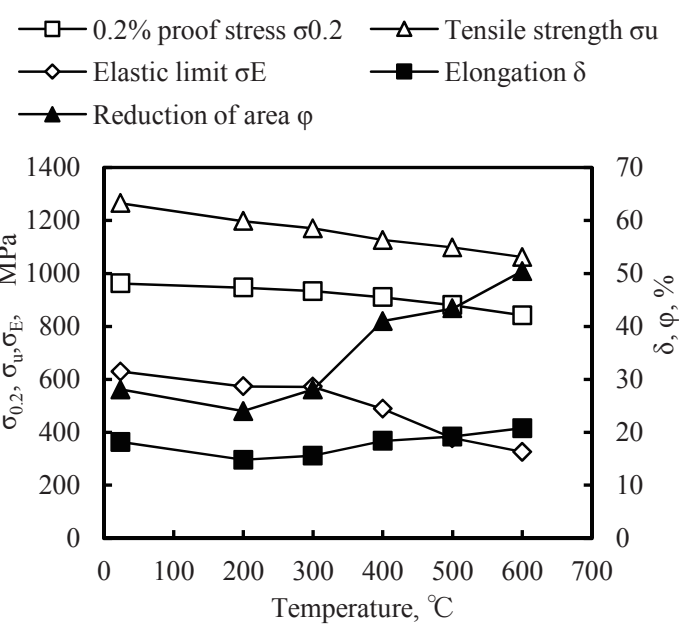

Fig. 1 Mechanical properties of test material.

Table 2 Modulus of elasticity E of Alloy $706^{15)}$

\begin{tabular}{c|c|c|c}
\hline Temperature, ${ }^{\circ} \mathrm{C}$ & $\mathrm{E}, \mathrm{GPa}$ & Temperature, ${ }^{\circ} \mathrm{C}$ & $\mathrm{E}, \mathrm{GPa}$ \\
\hline 20 & 210 & 400 & 188 \\
\hline 200 & 206 & 500 & 181 \\
\hline 300 & 200 & 600 & 174 \\
\hline
\end{tabular}

Table 3 Matrix of creep tests for creep strain equation.

\begin{tabular}{c|c}
\hline Temperature, ${ }^{\circ} \mathrm{C}$ & Stress, $\mathrm{MPa}$ \\
\hline 570 & $805,840,880$ \\
\hline 600 & $750,800,850$ \\
\hline 630 & $650,685,735$ \\
\hline
\end{tabular}

Table 4 Constants for creep strain equation of test material.

\begin{tabular}{c|c|c|c}
\hline Temperature, ${ }^{\circ} \mathrm{C}$ & $\mathrm{A}$ & $\mathrm{n}$ & $\mathrm{m}$ \\
\hline 570 & $6.64 \times 10^{-55}$ & 17.9 & -0.328 \\
\hline 600 & $6.15 \times 10^{-56}$ & 18.5 & -0.345 \\
\hline 630 & $5.88 \times 10^{-38}$ & 12.5 & -0.411 \\
\hline
\end{tabular}

$\mathrm{SP}$ 材の $450^{\circ} \mathrm{C} と 500^{\circ} \mathrm{C}$ 熱時効処理試験に関しては, 温 度，時間ごとに試験片を1個ずつ準備して，計6個の試験 片で試験を実施し，LP材に関しては，各温度2個ずつの 試験片を準備して, 計4個の試験片で試験を実施した。 また， SP材の $570^{\circ} \mathrm{C}, 600^{\circ} \mathrm{C}$ おび $630^{\circ} \mathrm{C}$ 熱時効処理試 験に関しては，温度ごとに1個ずつの試験片を準備して, 計3個の試験片で試験を実施した。

残留応力は，X線回折法にて測定した。Table 8に測定 条件を, Fig. 3に残留応力測定位置を示す. X線弾性定数 は装置に内蔵されているデータベースの中の相当材の 值を用いた。 


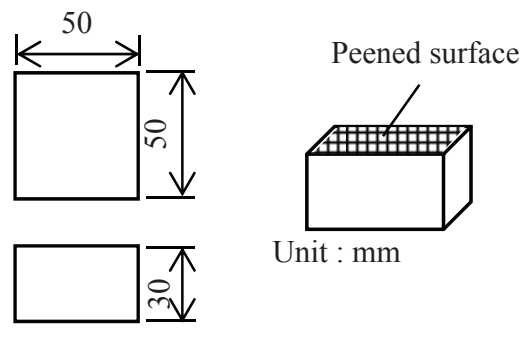

Fig. 2 Test specimen.

Table 5 Laser peening condition.

\begin{tabular}{l|c}
\hline Pulse energy $(\mathrm{mJ})$ & 200 \\
\hline Spot size $(\mathrm{mm})$ & 0.6 \\
\hline Pulse number density $\left(\mathrm{pulse} / \mathrm{mm}^{2}\right)$ & 50 \\
\hline
\end{tabular}

Table 6 Matrix of thermal aging treatment test for SP specimens.

\begin{tabular}{c|c|c|c}
\hline Temperature $\left({ }^{\circ} \mathrm{C}\right)$ & \multicolumn{3}{|c}{ Time $(\mathrm{h})$} \\
\hline 450 & 0,1000 & 0,3000 & 0,10000 \\
\hline 500 & 0,1000 & 0,3000 & 0,10000 \\
\hline 570 & \multicolumn{3}{|c}{$0,100,300,1000$} \\
\hline 600 & \multicolumn{3}{|c}{$0,100,300,1000$} \\
\hline 630 & \multicolumn{3}{c}{} \\
\hline
\end{tabular}

Table 7 Matrix of thermal aging treatment test for LP specimens.

\begin{tabular}{c|c|c}
\hline Temperature $\left({ }^{\circ} \mathrm{C}\right)$ & \multicolumn{2}{|c}{ Time $(\mathrm{h})$} \\
\hline 450 & $0,100,1000,3000$ & 0,10000 \\
\hline 500 & $0,100,1000,3000$ & 0,10000 \\
\hline
\end{tabular}

Table 8 Parameters for X-ray diffraction method.

\begin{tabular}{l|c}
\hline Characteristic X-ray & $\mathrm{Mn}-\mathrm{K} \alpha$ \\
\hline Diffraction plane & 311 \\
\hline Diffraction angle, deg & 151.88 \\
\hline Aperture diameter, $\mathrm{mm}$ & $\phi 2$ \\
\hline Oscillation, deg. & \pm 3 \\
\hline Voltage, $\mathrm{kV}$ & 17 \\
\hline Current, $\mathrm{mA}$ & 1.6 \\
\hline
\end{tabular}

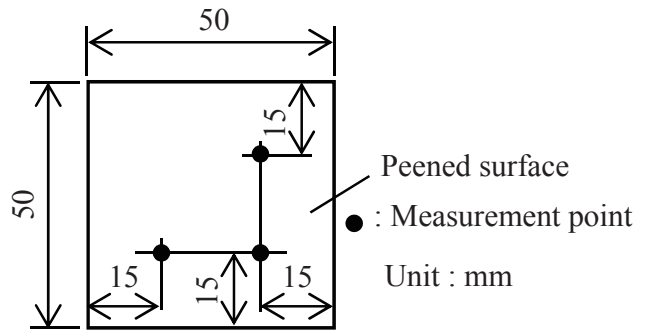

Fig. 3 Residual stress measurement points.

熱時効処理前にFig. 3に示すような表面の3箇所の残留 応力を測定し，熱時効処理後には表面の3箇所とそのう ち1箇所の内部の残留応力を測定した. 内部の残留応力 分布は, 電解研磨を行い, そのつど新たに発現した面 (約 $\phi 10 \mathrm{~mm})$ の残留応力測定をすることで求めた。 熱時効 処理前の表面残留応力測定は各試験片に対して実施し ているが，内部残留応力測定に関しては，SP材では， $570^{\circ} \mathrm{C}$ おび $600^{\circ} \mathrm{C}$ の熱時効処理用試験片の測定を行い,
試験片で差異のないことを確認して，それらの平均值を 熱時効処理前の残留応力值として用いている. 所定の時 間の熱時効処理後に加熱炉から試験片を取り出して, 表 面の残留応力を測定, 最も長い時間の熱時効処理の終了 後に内部残留応力測定も実施することにより, 残留応力 に及ぼす温度の影響を評価した。

\section{3 結 果}

\section{$3.1 \mathrm{SP}$ 材の残留応力測定結果}

Fig. 4, Fig. 5 および Fig. 6 に SP 材の $450^{\circ} \mathrm{C}$ と $500^{\circ} \mathrm{C} の$ 熱時効処理試験結果を示す. 複数点および誤差が大きい 場合には同じ位置で複数回の残留応力測定をしている が，測定值が同程度の值であったため平均值をプロット している，また，直交する 2 方向の残留応力の值も同程 度の值であったため， 1 方向の応力のみをプロットして いる.

Fig. 4 は, $450^{\circ} \mathrm{C}$ と $500^{\circ} \mathrm{C}$ 熱時効処理試験結果であり, 表面残留応力測定結果である. 熱時効処理前のピーニン グ施工面の残留応力は高い圧縮で，その值は-670〜 $-750 \mathrm{MPa}$ であり, 熱時効処理により表面の圧縮残留応力 は変化し，その変化量は $300 \mathrm{MPa}$ 程度であった。残留応 力は短時間で大きく変化して，熱時効処理時間でばらつ きがあるものの 3000 時間後と 10000 時間後の残留応力 の值は概ね同じで時間の経過による残留応力の変化は 小さい. $450^{\circ} \mathrm{C}$ と $500^{\circ} \mathrm{C}$ 結果に明確な差は認められない.

Fig. 5 に $500^{\circ} \mathrm{C}$ の熱時効処理前後の内部残留応力測定結 果を示す. 熱時効処理前の内部残留応力分布は, $50 \mu \mathrm{m}$ で圧縮の最高值-930MPa を示し, それより深い位置では 圧縮残留応力は低下し, 圧縮残留応力が生じている深さ は約 $250 \mu \mathrm{m}$ である. 熱時効処理後の内部残留応力分布に はばらつきがあり，たとえば，3000 時閒後の残留応力分 布の最大值は，熱時効前の最大值よりも大きく，深い位 置にあり，これが施工や個体差によるものなのかは明確 ではないが, 浅い位置の比較的高い残留応力はある一定 值まで変化している傾向がある. 10000 時間後の残留応 力は，短い時間の熱時効処理後の残留応力よりも変化し ているものの熱時効処理時間が内部残留応力に及ぼす 明確な傾向が認められない. 圧縮残留応力の深さはいず れの熱時効処理時間の結果においても熱時効処理前と 同じ $250 \mu \mathrm{m}$ である.この結果の傾向は， $450^{\circ} \mathrm{C}$ の熱時効 処理試験についても同様であった.

Fig. 6 に， $450^{\circ} \mathrm{C}$ と $500^{\circ} \mathrm{C}$ の熱時効処理試験の 10000 時 間後の内部残留応力分布を示す. Fig. 5 と同様に, 浅い 位置の比較的高い残留応力はある值まで変化しており, それよりも深い位置においても変化している傾向があ る. 圧縮残留応力の深さは熱時効処理前と同程度である. $450^{\circ} \mathrm{C}$ と $500^{\circ} \mathrm{C}$ の測定結果を比較すると, $500^{\circ} \mathrm{C}$ の残留応 力の変化のほうがわずかに大きい.

$450^{\circ} \mathrm{C}$ おび $500^{\circ} \mathrm{C}$ 熱時効処理試験の結果, 内部残留 応力分布にわずかに差があるものの温度の影響は認め られなかった。また，熱時効処理時間の影響も明確に認 められず，短時間側で表面残留応力の変化が認められる 
ものの, 10000 時間の熱時効後においても残留応力は同 程度で-400MPa 以上の圧縮残留応力であった.

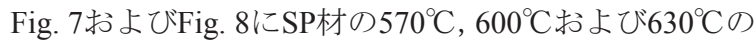
熱時効処理試験結果を示す. $450^{\circ} \mathrm{Cおよび} 500^{\circ} \mathrm{C}$ の測定と 同様に複数点および誤差が大きい場合には同じ位置で 複数回の残留応力測定をしているが，測定值が同程度の 值であったため平均值をプロットしている，また，直交 寸る2方向の残留応力の值も同程度の值であったため, 1 方向の応力のみをプロットしている.

Fig. 7に示寸表面残留応力測定結果については, $450^{\circ} \mathrm{C}$ と $500^{\circ} \mathrm{C}$ の結果と同様に, 熱時効処理前のピーニング施 工面の残留応力は高い圧縮で, その值は-720〜-750MPa である. 熱時効処理により表面の圧縮残留応力值は変化 しているものの，その低下量は $450^{\circ} \mathrm{C}$ と $500^{\circ} \mathrm{C}$ 低下量よ り大きかった. 残留応力の変化量は $630^{\circ} \mathrm{C}$ の熱時効処理 後の結果が最も大きく約 $480 \mathrm{MPa}, 570^{\circ} \mathrm{C}$ で最も小さく 340MPaであり，温度の影響が認められる。また，熱時 効処理時間の経過とともにわずかに変化している.

Fig. 8 に $570^{\circ} \mathrm{C} ， 600^{\circ} \mathrm{C}$ よび $630^{\circ} \mathrm{C}$ の 1000 時間の熱時効 処理後の内部残留応力測定結果を示す. $450^{\circ} \mathrm{C}$ おび $500^{\circ} \mathrm{C}$ の結果と同様に, 浅い位置の比較的高い残留応力 はある值まで緩和しており，その值は $450^{\circ} \mathrm{C} と 500^{\circ} \mathrm{C}$ の結 果より低く，それよりも深い位置においても変化してい

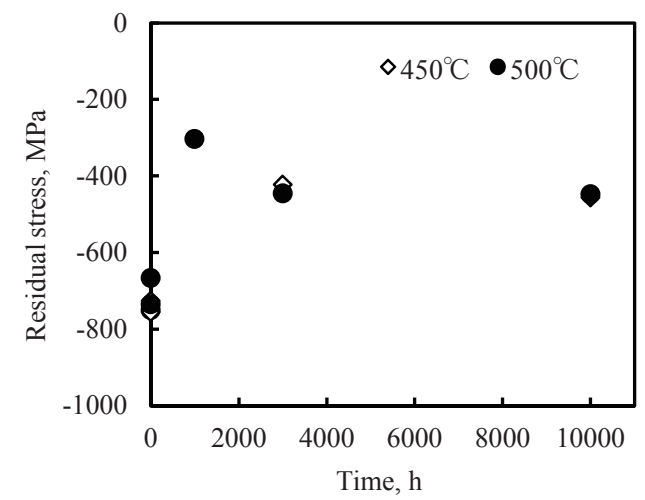

Fig. 4 Relationship between surface residual stress and time for SP specimens (Temperature : $450^{\circ} \mathrm{C}$ and $500^{\circ} \mathrm{C}$ ).

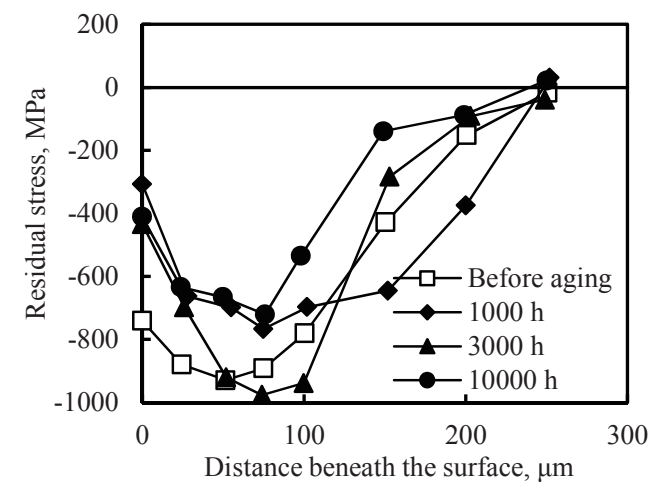

Fig. 5 Stress distribution beneath the surface after thermal aging treatment test for SP specimens (Temperature : $500^{\circ} \mathrm{C}$ ).

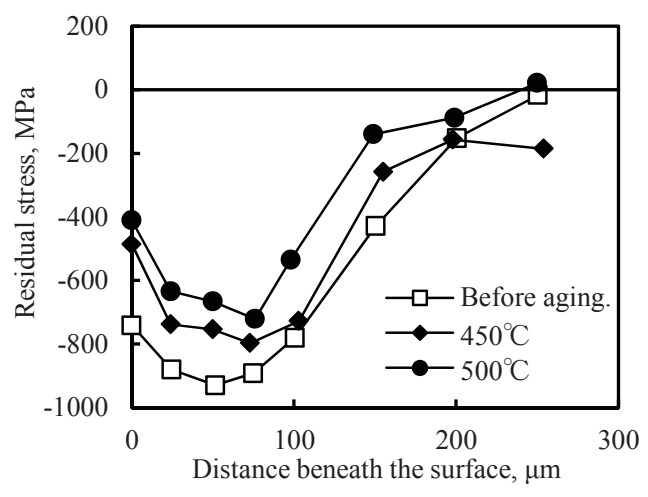

Fig. 6 Stress distribution beneath the surface after $10000 \mathrm{~h}$ thermal aging treatment for SP specimens (Temperature : $450^{\circ} \mathrm{C}$ and $\left.500^{\circ} \mathrm{C}\right)$.

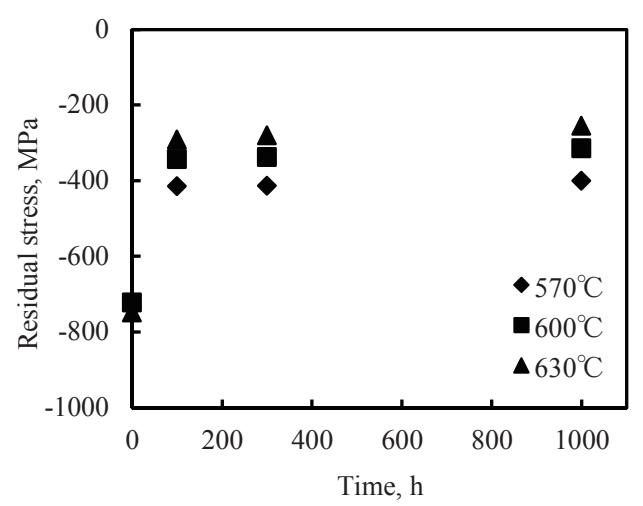

Fig. 7 Relationship between surface residual stress and time for SP specimens (Temperature : $570^{\circ} \mathrm{C}, 600^{\circ} \mathrm{C}$ and $630^{\circ} \mathrm{C}$ ).

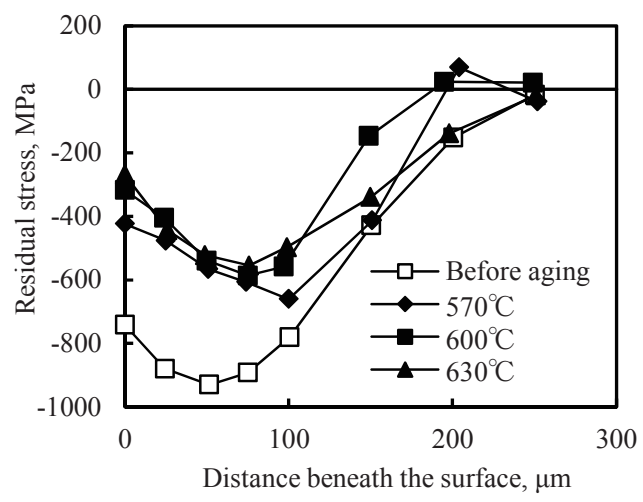

Fig. 8 Stress distribution beneath the surface after $1000 \mathrm{~h}$ thermal aging treatment for SP specimens (Temperature : $570^{\circ} \mathrm{C}, 600^{\circ} \mathrm{C}$ and $\left.630^{\circ} \mathrm{C}\right)$.

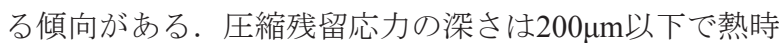
効処理前よりわずかに浅くなっている. 残留応力の変化 量に及ぼす温度の影響は明確には認められない.

$570^{\circ} \mathrm{C} ， 600^{\circ} \mathrm{C}$ おび $630^{\circ} \mathrm{C}$ 熱時効処理試験の結果， 表面残留応力に関しては, $450^{\circ} \mathrm{C}$ と $500^{\circ} \mathrm{C}$ の結果と同様に 短時間側で大きく変化する傾向が認められた. 1000 時間 
の熱時効処理後において，温度と時間の影響が認められ， さらに変化しているものの-250MPa 以上の圧縮残留応力 であった。 内部残留応力分布に温度の影響は明確には認 められなかった.

\subsection{LP 材の残留応力測定結果}

Fig. 9 および Fig. 10 に LP 材の $450^{\circ} \mathrm{C}$ と $500^{\circ} \mathrm{C}$ 熱時効 処理試験結果を示す. SP 材と同様に, 複数点および誤差 が大きい場合には同じ位置で複数回の残留応力測定を しているが，同程度の值であったため平均值をプロット している．図にレーザの走査方向を示すように，直交す る 2 方向の残留応力の值はレーザの走査寸る方向により やや異なっており,これは一般的な LP の傾向である ${ }^{4)}$.

Fig. 9 および Fig. 10 に示す $450^{\circ} \mathrm{C}$ と $500^{\circ} \mathrm{C}$ 表面残留 応力測定結果は, 各温度で 2 個の試験片を用いて測定し た結果である。熱時効処理前のピーニング施工面の残留 応力は高い圧縮で，その值は-440〜-820MPa であり，熱 時効処理により表面の $\mathrm{x}$ 方向の圧縮残留応力はわずかに 変化, $\mathrm{y}$ 方向の圧縮残留応力は $\mathrm{x}$ 方向よりもやや大きく 変化し, その変化量は $100 \mathrm{MPa}$ 程度であり, SP 材よりも 小さかった．SP材と同様，短時間で応力は変化して，熱 時効処理時間でばらつきがあるものの時間の経過によ る残留応力の変化は小さい. $450^{\circ} \mathrm{C}$ と $500^{\circ} \mathrm{C}$ の結果には明 確な差は認められない.

Fig. 11にLP材の熱時効処理前の内部残留応力分布と $450^{\circ} \mathrm{C}$ おび $500^{\circ} \mathrm{C}$ の 3000 時間熱時効処理試験後の内部 残留応力測定結果を示す. 熱時効処理前の圧縮残留応力 の深さは $800 \mu \mathrm{m}$ 以上でSP材よりも深い. 熱時効処理後の 表面近傍の高い圧縮残留応力は変化しており，圧縮残留 応力の深さはやや浅くなっているものの, SP材に比べる と熱時効処理前後の残留応力分布の変化は小さい.

\section{4 考 察}

\section{1 温度変化による残留応力緩和予測}

クリープ試験結果から, 熱時効処理試験の応力緩和を

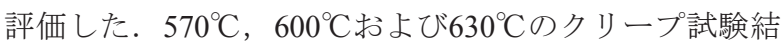
果から同じ温度の熱時効処理試験結果を予測し，さらに, その結果をもとに、 $450^{\circ} \mathrm{C}$ と $500^{\circ} \mathrm{C}$ 熱時効処理試験後の 応力緩和を評価した. $450^{\circ} \mathrm{C}$ と $500^{\circ} \mathrm{C}$ の熱時効処理試験結 果の評価に関しては、測定した2方向の残留応力が同じ SP材の結果を評価し、その結果に基づいて、2方向の残 留応力が異なるLP材の結果を評価した.

前項に測定結果を述べたように，残留応力は，短時間 で大きく変化し，その後の変化は温度により異なり，変 化はわずかかほとんど認められなかった。その緩和挙動 は, 温度変化による変化と高温保持中の変化の 2 段階で 評価できると考えられる，温度変化による残留応力の変 化は機械的特性の変化が原因と考えられ，高温保持中の 変化はクリープひずみ発生に起因する残留応力緩和と 考えられる.

温度変化による残留応力の変化は, 温度が高温になっ た時の応力が弾性限度または $0.2 \%$ 耐力を超える場合に, 新たな塑性ひずみが発生して低下すると予想した。高温
での弾性限度と $0.2 \%$ 耐力をそれぞれ $\sigma_{E, H T}$ と $\sigma_{0.2 H T}$, 室温 と高温のヤング率をそれぞれ $E_{R T}, E_{H T}$ とすると, 室温で 測定を行っているため, $\sigma_{E, H T}$ と $\sigma_{0.2, H T}$ で予測される温度 変化後の残留応力はそれぞれ次式で示される.

$$
\begin{aligned}
& \sigma(E)=E_{R T}\left(\sigma_{E, H T} / E_{H T}\right) \\
& \sigma(0.2)=E_{R T}\left(\sigma_{0.2, H T} / E_{H T}\right)
\end{aligned}
$$

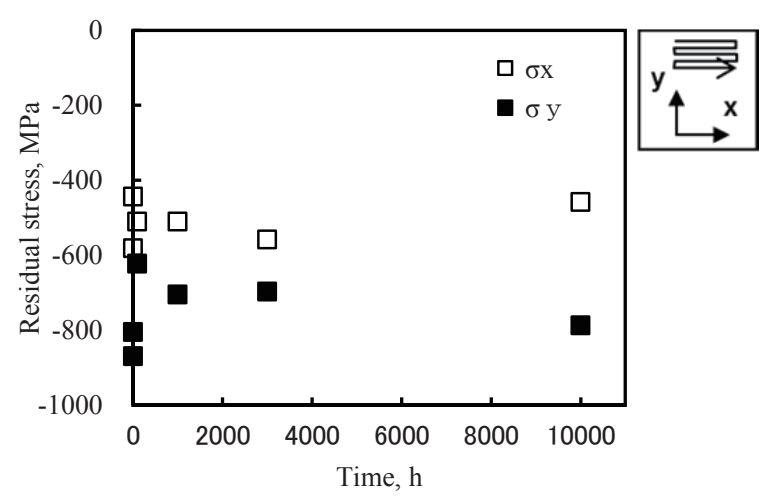

Fig. 9 Relationship between surface residual stress and the time for LP specimens (Temperature : $450^{\circ} \mathrm{C}$ ).

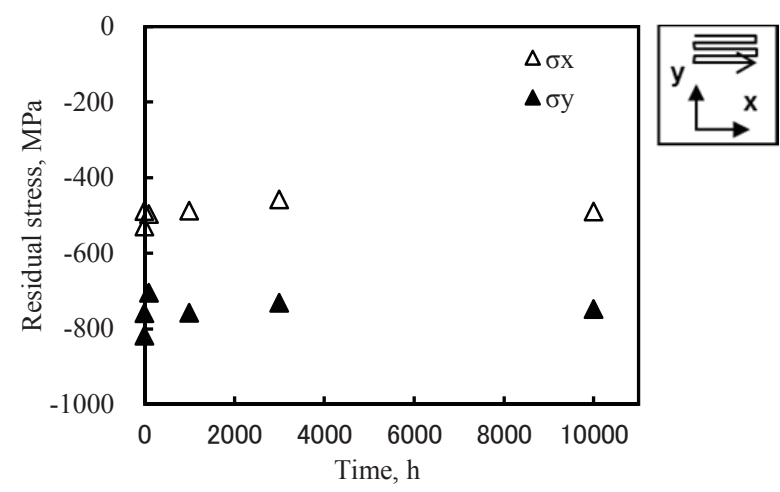

Fig. 10 Relationship between surface residual stress and time for LP specimens (Temperature: $500^{\circ} \mathrm{C}$ ).

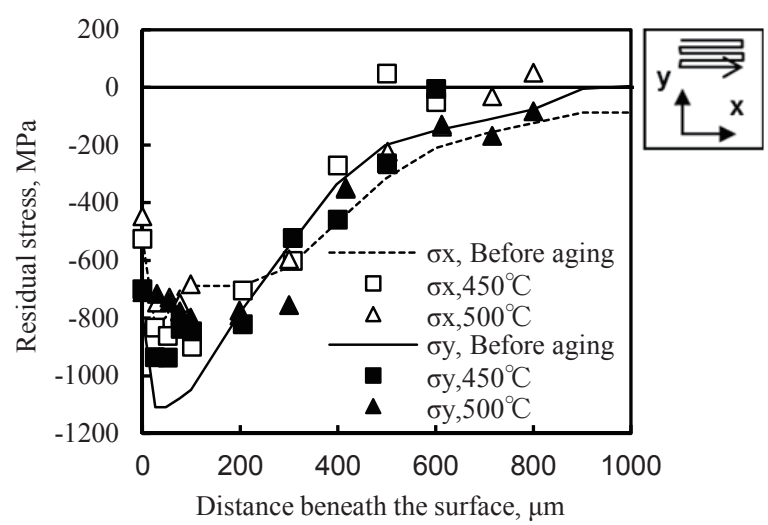

Fig. 11 Stress distribution beneath the surface after $3000 \mathrm{~h}$ thermal aging treatment for LP specimen (Temperature : $450^{\circ} \mathrm{C}$ and $\left.500^{\circ} \mathrm{C}\right)$. 
ただし， $\sigma(E), \sigma(0.2)$ とも，高温の值が室温の弾性限度 や $0.2 \%$ 耐力よりも高い場合には, 室温のそれらの值を用 いた. Fig. 12 に，それぞれの熱時効処理試験における短 時間側の残留応力測定值と予測值 $\sigma(E), \sigma(0.2)$ をプロッ 卜した図を示す．LP材に関しては， $\mathrm{x}$ 方向応力 $\sigma_{x}$ と $\mathrm{y}$ 方向応力 $\sigma_{y}$ の值が異なるため, 次式に示す Mises 相当応 力 $\sigma_{e q}$ で評価した.

$$
\sigma_{e q}=\sqrt{\left\{\left(\sigma_{x}-\sigma_{y}\right)^{2}+\sigma_{x}^{2}+\sigma_{y}^{2}\right\} / 2}
$$

なお， $\sigma_{e q}$ を求める際には，平面応力状態で, $\mathrm{x}$ 方向と $\mathrm{y}$ 方向が主応力方向に一致すると仮定した．同じ仮定で評 価すると，SP材の $\sigma_{x}$ と $\sigma_{y}$ の值はほぼ同じで，それぞれ $\sigma_{e q}$ と同じ值となるため，SP材に関しては1方向の応力を示 している。また， $\mathrm{SP}$ 材の $450^{\circ} \mathrm{C} と 500^{\circ} \mathrm{C}$ 結果に関しては 1000 時間後と 3000 時間後の測定結果を，SP材の $570^{\circ} \mathrm{C}$ ら $630^{\circ} \mathrm{C}$ の結果に関しては 100 時間後の測定結果を，そし て， LP材の $450^{\circ} \mathrm{C} と 500^{\circ} \mathrm{C}$ 結果に関しては 100 時間後の 測定結果を示寸.

Fig. 12に示すように，短時間側の残留応力は， $\sigma(0.2)$ よりも低く， $\sigma(E)$ に近い值を示している。そのため，加 熱直後の残留応力は弾性限度で予測可能と考えて, それ 以降の加熱保持中の予測を行った.

\section{2 加熱保持中の残留応力緩和予測}

加熱保持中の残留応力緩和は，クリープひずみ発生に よるものと考えられる.クリープひずみ発生による残留 応力予測式を考える.

ピーニングで生じている残留応力は表面から $1 \mathrm{~mm}$ 下で，熱時効処理試験に用いている試験片の板厚 $30 \mathrm{~mm}$ に比べると小さく，全ひずみが一定と考えられる．全ひ ずみが一定の場合，次式のように示される。

$$
\varepsilon_{e}+\varepsilon_{p}+\varepsilon_{c}=\text { 一定 }
$$

ここで， $\varepsilon_{e}$ は弾性ひずみ， $\varepsilon_{p}$ は塑性ひずみ， $\varepsilon_{c}$ はクリー プひずみである。

熱時効処理中に新たな塑性ひずみが発生しないと仮 定すると, 弾性ひずみ $\varepsilon_{e}$ とクリープひずみ $\varepsilon_{c}$ の和は一定 となるため, 熱時効処理中にはクリープひずみ $\varepsilon_{c}$ が増加 した分，弾性ひずみが $\varepsilon_{e}$ 減少すると考えられる。式 (5) を時間で微分して, ヤング率 $E$ を乗じると, 応力の時間 変化 $d \sigma / d t$ は次式のように示される.

$d \sigma / d t=d E \varepsilon_{e} / d t=-d E \varepsilon_{c} / d t$

この式に，式（1）を代入すると次式のように示され る.

$$
d \sigma / d t=-E A \sigma^{n} t^{m}
$$

さらに，この式を時間0から時間 $\tau$ まで積分すると， $\tau$ 時間後の残留応力 $\sigma_{\tau}$ は次式のように求まる.

$$
\sigma_{\tau}=\left[(1-n)\left\{\left(\sigma_{0}^{1-n} /(1-n)-E(A / 100) \tau^{m+1} /(m+1)\right)\right\}\right]^{1 /(1-n)}
$$

ここで， $\sigma_{0}$ は初期応力である. Fig. 12 から温度変化に よる残留応力の変化が $\sigma(E)$ で予測可能であることがわ かったため, 初期応力として $\sigma_{E, H T}$ を用いて加熱保持中の 残留応力の変化を予測した。
Fig. 13 に $570^{\circ} \mathrm{C}$ から $630^{\circ} \mathrm{C} の \mathrm{SP}$ 材の熱時効処理試験 結果と予測結果の比較図を示す。その結果, 予測結果は 測定結果と同様で, 残留応力は試験の初期に大きく変化 し, その後はほとんど変化しなかった。温度の影響に関 しても, 試験結果と予測結果は同様であり， $630^{\circ} \mathrm{C}$ 残 留応力の変化が最も大きかった。 クリープひずみ発生に よる応力の緩和量は $1 \%$ 以下であった。この理由は，加 熱の初期に残留応力が弾性限度まで低下したためと考 えられる，以上のことから，式（8）を用いて，熱時効 処理中の残留応力緩和挙動を予測できることを確認し た.

次に, $450^{\circ} \mathrm{C}$ と $500^{\circ} \mathrm{C}$ 残留応力の変化を予測する。こ の場合， $450^{\circ} \mathrm{C}$ と $500^{\circ} \mathrm{C}$ のリープひずみ式の代わりに， 高温側のクリープひずみ式を用いるが，温度と時間の換 算には次式に示す Larson-Miller パラメータ LMP を用い た.

$L M P=T\left(C+\log _{10} t_{r}\right)$

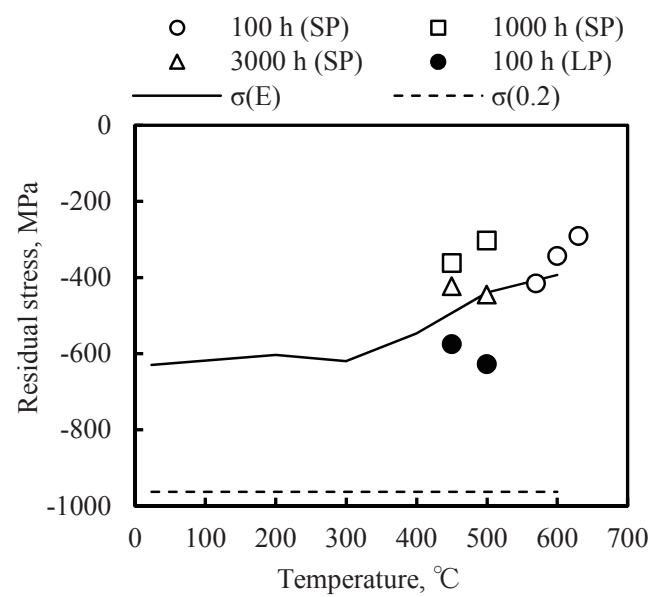

Fig. 12 Relationship between surface residual stress and temperature just after thermal aging treatment with predicted stress.

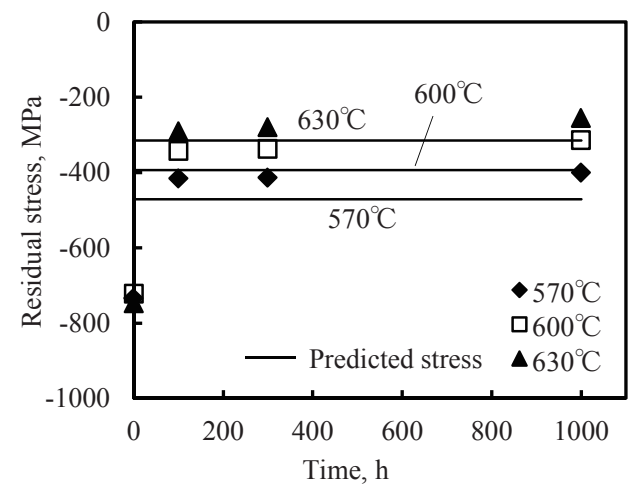

Fig. 13 Comparison results between the predicted stress and measurements during thermal aging treatment for SP specimen (Temperature : $570^{\circ} \mathrm{C}, 600^{\circ} \mathrm{C}$ and $630^{\circ} \mathrm{C}$ ). 


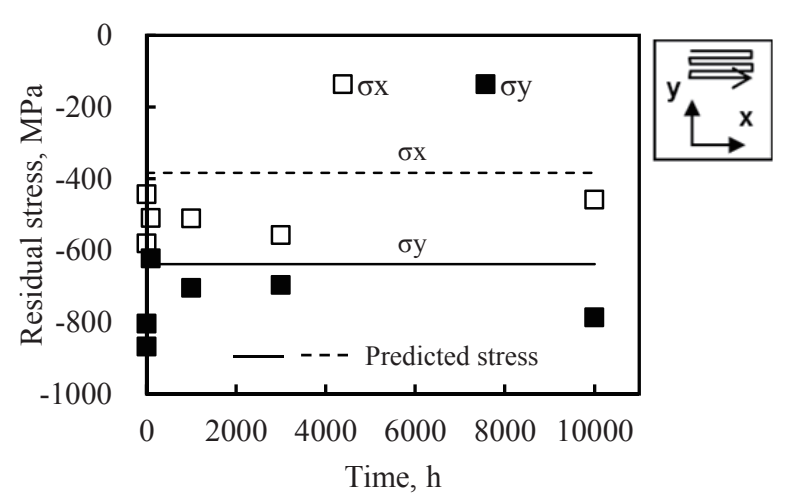

Fig. 14 Comparison results between the predicted stress and measurements for LP specimen (Temperature : $450^{\circ} \mathrm{C}$ ).

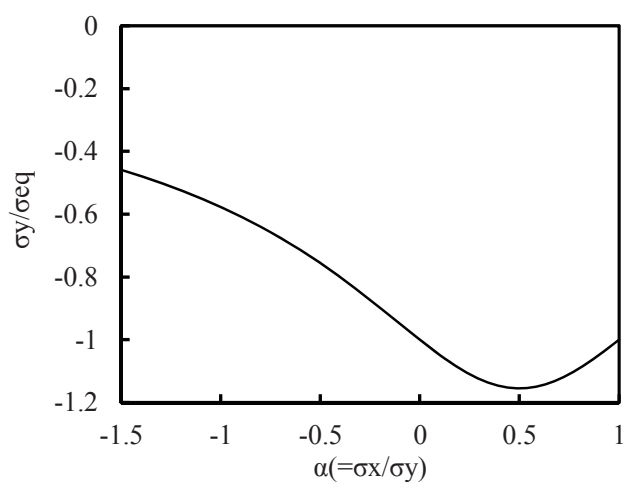

Fig. 15 Relationship between the ratio of stress components and the ratio to equivalent stress of larger compressive residual stress.

ここで, $T$ は絶対温度 $(\mathrm{K}), t_{r}$ は時間 $(\mathrm{h}), C$ は定数 であり，Cの值として 20 を使用した.

この式を用いて, 温度が近い $500^{\circ} \mathrm{C}$ と $570^{\circ} \mathrm{C}$ の時間換 算を行った。その結果, $570^{\circ} \mathrm{C} の 1000$ 時間に相当する $500^{\circ} \mathrm{C}$ の時間は約 12 万時間であった. $570^{\circ} \mathrm{C} の 1000$ 時間 に対する残留応力の変化はわずかであり, $450^{\circ} \mathrm{C}$ と $500^{\circ} \mathrm{C}$ の熱時効処理では，加熱保持中に残留応力はほとんど変 わらないと予想でき, 短時間側の応力変化のみで熱時効 処理による残留応力の変化を予測可能なことがわかっ た.

\subsection{LP 材の残留応力緩和予測}

LP 材のように $\sigma_{x}$ と $\sigma_{y}$ の值が異なる場合には, Mises 相当応力 $\sigma_{e q}$ による予測を示唆したが， $\sigma_{x}$ と $\sigma_{y}$ の各応力 成分の残留応力を予測する。ここでは, 2 方向の応力の 比 $\alpha\left(=\sigma_{x} / \sigma_{y}\right)$ が緩和前後で変わらないと仮定して予測を した. Fig. 14 は $450^{\circ} \mathrm{C}$ の LP 材の残留応力予測結果である. その結果，予測值は測定結果よりやや低い圧縮残留応力 であるものの，概ね一致する結果を得ることができた. 以上の結果から, 同様の方法で SP 材と LP 材の熱時効処 理中の残留応力の変化を予測することが可能なことが わかった。

次に, SP 材と LP 材の残留応力を比較すると, LP 材
の $\sigma_{y}$ は，SP 材よりも高い值を示している，そのことか ら， 2 方向の応力比 $\alpha$ を制御することで, 望む方向に高 い圧縮残留応力を残すことができると考え, 検討を行っ た. $\sigma_{y}$ が $\sigma_{x}$ より高い圧縮残留応力とした場合， $\sigma_{e q}$ と $\sigma_{y}$ の関係は次式のようにあらわされる.

$$
\sigma_{e q}=-\sqrt{\alpha^{2}-\alpha+1} \times \sigma_{\mathrm{y}}
$$

Fig. 15 は $\alpha$ と $\sigma_{y} / \sigma_{e q}$ の関係を示す図である. $\alpha$ が正の時 は $\sigma_{x}$ も圧縮, 負の時は $\sigma_{x}$ が引張を示している. この図か ら， $\alpha$ が 0.5 の時に， $\sigma_{e q}$ に対する $\sigma_{y}$ は極小值を示してい る. すなわち, $\sigma_{y}$ が $\sigma_{x}$ の 2 倍の圧縮残留応力の場合に, 熱時効処理後の $\sigma_{y}$ の圧縮残留応力が最も高く維持される ものと考えられる.

\section{5 結 言}

ガスタービンのホイールの材料として使用されている $\mathrm{Ni}$ 基超合金 Alloy 706 の試験片で $450^{\circ} \mathrm{C}$ から $630^{\circ} \mathrm{C}$ までの 熱時効処理試験を実施し, 残留応力緩和挙動を評価する とともに，予測手法を検討した，得られた結果を以下に 示す.

(1) ショットピーニング（SP）およびレーザピーニン グ（LP）を施工した試験体の表面残留応力は高い 圧縮であり, 熱時効処理試験後の残留応力は, いず れの温度においても圧縮が維持されることを確認 した. 残留応力の変化は温度が高いほど大きい傾向 が認められ, また、熱時効時間が残留応力緩和に及 ぼす影響は小さい.

（2）SP および LP を施工した試験体の内部残留応力は, 表面残留応力と同様，圧縮を維持していた。

（3）機械的特性の温度依存性とクリープひずみ式から, 圧縮残留応力の緩和挙動を評価可能であることを 示した. 残留応力は短時間で緩和するために, 機械 的特性の温度依存性が支配的であることを示した。 すなわち, 残留応力は加熱の初期の段階で生じ, 保 持温度の弾性限度とヤング率からその大きさを評 価可能なことがわかった.

(4) LP 材のように残留応力の大きさが方向により異な る大きさをもつ場合には, 緩和前後で 2 方向の残留 応力の応力比が変化しないと仮定し, Mises 相当応 力を用いることで, 残留応力緩和量を評価可能なこ とが分かった．また，残留応力の方向性を制御する ことで，1 方向に高い圧縮残留応力を残すことがで きる可能性を示した.

\section{参 考 文 献}

1) M. Obata, T. Kubo, M. Yoda, R. Saeki and T. Ishikawa, "Relaxation behavior of compressive residual stress formed by laser peening" , Proceedings of M\&M2009 Conference of JSME, OS1435 (2009).

2) S. Taira and Y. Murakami, "On the changes of residual stresses produced by shot peening due to repeated stressing", Journal of the Japan Society for Testing Materials, Vol.8, No.70, pp.607-614 (1959).

3) D. Viereck, D. Löhe, O. Vöhringer and E. macherauch, "Relaxtion of residual stress in a nickel-base superalloy 
due to dislocation creep", Strength Metals and Alloys, 1991, Vol.1, pp.367-372 (1991).

4) H. Holzapfel, V. Schulze, O. Vöhringer and E. macherauch, "Residual stress relaxation in an AISI 4140 steel due to quasistatic and cyclic loading at higher temperature", Materials Science and Engineering A248, pp.9-18 (1998).

5) M. Khadhraoui, W. Cao, L. Castex and J. Y. Guédou, "Experimental investigations and modelling of relaxation behaviour of shot peening residual stresses at high temperature for nickel base superalloys", Materials Science and Technology, April, Vol.13, pp.360-367 (1997).

6) S. -B. Kim, A. Evans, J. Shackleton, G. Bruno, M. Preuss and P. J. Withers, "Stress relaxation of shot-peened UDIMET 720Li under solely elevated-temperature exposure and under isothermal fatigue", Metallurgical and Materials Transactions A, Vol.36A, November, pp.3041-3053 (2005).

7) Y. Sano, M. Kimura, K. Sato, M. Obata, A. Sudo, Y. Hamamoto, S. Shima, Y. Ichikawa, H. Yamazaki, M. Naruse, S. Hida, T. Watanabe and Y. Oono, "Development and application of laser peening system to prevent stress corrosion cracking of reactor core shroud", Proceedings of the 8th International Conference on Nuclear Engineering, Baltimore, ICONE8-8441 (2000).

8) Y. Sano, M. Obata and T. Yamamoto, "Residual stress improvement of weldment by laser peening", Journal of The Japan Welding Society, Vol.74, No.8, pp.525-528 (2005)

9) Y. Sano, "Laser peening for extending service life of components", Journal of The Surface Finishing Society of Japan, Vol.60, No.11, pp.698-703 (2009).

10) I. Chida, Y. Sano, K. Hirota, T. Inukai, R. Sumiya, H. Sasaki, I. Murakami, and H. Nomura, "Development of laser peening technology for low pressure turbine blades to improve fatigue properties", Proceedings of 10th Annual Conference of JSM, 2-1-D-1 (2013).

11) M. Obata, T. Kubo, Y. Sano, M. Yoda, N. Mukai, S. Shima and M. Kanno, "Development of stress improvement technique using pulse laser irradiation Evaluation of stress improvement for Type 304 stainless steel -“, Journal of the Society of Materials Science, Japan, Vol.49, No.2, pp.193-199 (2000).

12) Y. Sakino, Y. Sano, R. Sumiya, and Y.-C. Kim, "Fatigue life enhancement of fillet and butt welded joints after laser peening", Transactions of JWRI, Vol.41, No.1, pp.71-76 (2012)

13) Y. Sakino, K. Yoshikawa, Y. Sano, R. Sumiya and Y. -C. Kim, "A basic study for application of laser peening to large-scale steel structure", Quarterly Journal of the Japan Welding Society, Vol. 31, No.4, pp.231-237 (2013).

14) T. Sakai, K. Akita, S. Ohya, Y. Sano, and T. Saito, "The effect of static and fatigue loading on residual stress induced by laser peening", Journal of the Society of Materials Science, Japan, Vol.57, No.7, pp.648-653 (2008).
15) SPECIAL METALS, “INCONEL ${ }^{\circledR}$ alloy 706”, www.specialmetals.com/documents/Inconel\%20alloy\%2 0706.pdf (reference date 2014/07/17). 